\title{
Cyanamid let off lightly in litigation over vitamin formulation
}

In July, a US federal court ruled in favor of two University of Colorado researchers who claimed that American Cyanamid (Wayne, NJ) had wrongfully obtained patent rights to their prenatal vitamin formulation. Although the court awarded more than $\$ 44$ million in damages and an additional $\$ 1$ million in punitive damages, Cyanamid probably got away lightly. The hard lesson for the University of Colorado researchers, and others like them, is that because they did not actually patent their invention, they may have lost out on over $\$ 100$ million in punitive damages.

The two researchers, Robert Allen and Paul Seligman, conducted several studies between 1979 and 1980 on the absorption of iron from prenatal vitamins. Although some of these studies were conducted with Cyanamid,

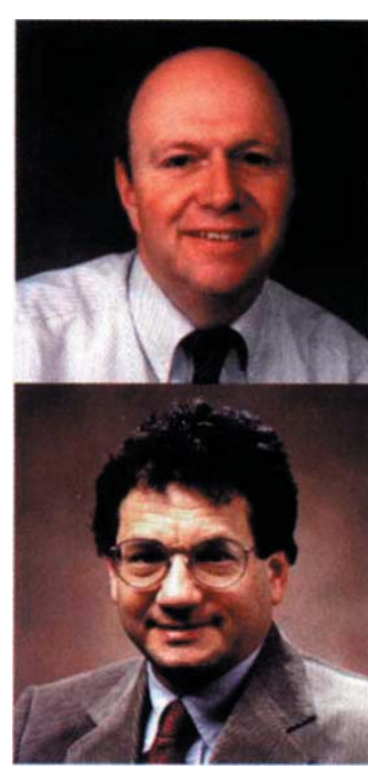

Robert Allen (top) and Paul Seligman (bottom) of the University of Colorado had a bone to pick with American Cynamid.
Patent owners may try to recover either the profits that they would have earned without the infringement, or a reasonable royalty. Where the infringement is willful rather than accidental, the patent owner may even recover attorneys' fees and three times the normal amount of money damages. Because the university researchers had not applied for their own patent, patent infringement had not occurred.

Nevertheless, the court ruled that the company was liable for fraud, unjust enrichment, and copyright infringement. The judge wrote that "Cyanamid wantonly disregarded the integrity of the doctors' research. . . Cyanamid's indifference and its consequent injury to the fragile nature of the creative process in scientific research cannot go unnoticed or unpunished." The court awarded a "reasonable royalty" amounting to $12 \%$ of the vitamin's actual and projected sales between 1982 and 2001. But it did not order Cyanamid to pay out the profits it had made.

In effect, the company has not been punseveral were performed independently. Ultimately, their work led to an improved formulation, which they did not patent. In 1981, Allen and Seligman prepared to publish their findings and sent a complimentary copy of their manuscript to a colleague, Leon Ellenbogen, at Cyanamid. Unbeknownst to the two researchers, Ellenbogen filed a patent application on the formulation and named himself as the sole inventor. The application copied information and figures from the University of Colorado researchers' manuscript. Cyanamid subsequently enforced the patent on several occasions to eliminate generic competition.

Twelve years later, in 1993, Allen and Seligman learned (from Ellenbogen, in fact) of the patent. They and the University of Colorado filed suit, claiming that American Cyanamid's actions had cost them the opportunity to benefit financially from their development of the new formulation. But what were the damages? In most intellectual property disputes, the person suing has a patent covering the invention.

Ken Chahine and Bart Giddings are patent attorneys at Madson \& Metcalf, Salt Lake City,UT (chahine@mmlaw.com; giddings@mmlaw.com). entists were not "inventors." A similar conflict brewed between Myriad Genetics (Salt Lake City, UT) and the NIH when Myriad omitted the names of NIH researchers from patent applications covering the breast cancer susceptibility gene, BRCA1. Myriad and NIH settled their dispute, with Myriad agreeing to name two NIH scientists as coinventors on the patent applications. Immunex (Seattle, WA) and Cistron (Pine Brook, NJ) also settled an inventorship dispute in which Cistron accused Immunex of pirating interleukin-1 sequence data from a paper submitted for publication in Nature.

These cases highlight the need for inventors to understand patent policy and to protect their intellectual property. In fact, universities are becoming more sophisticated about intellectual property issues, according to Michael Gabridge, director of the University of Colorado's technology transfer company. "Universities will no longer stand by and watch their intellectual property be exploited," he says.

Ken Chahine and Bart Giddings

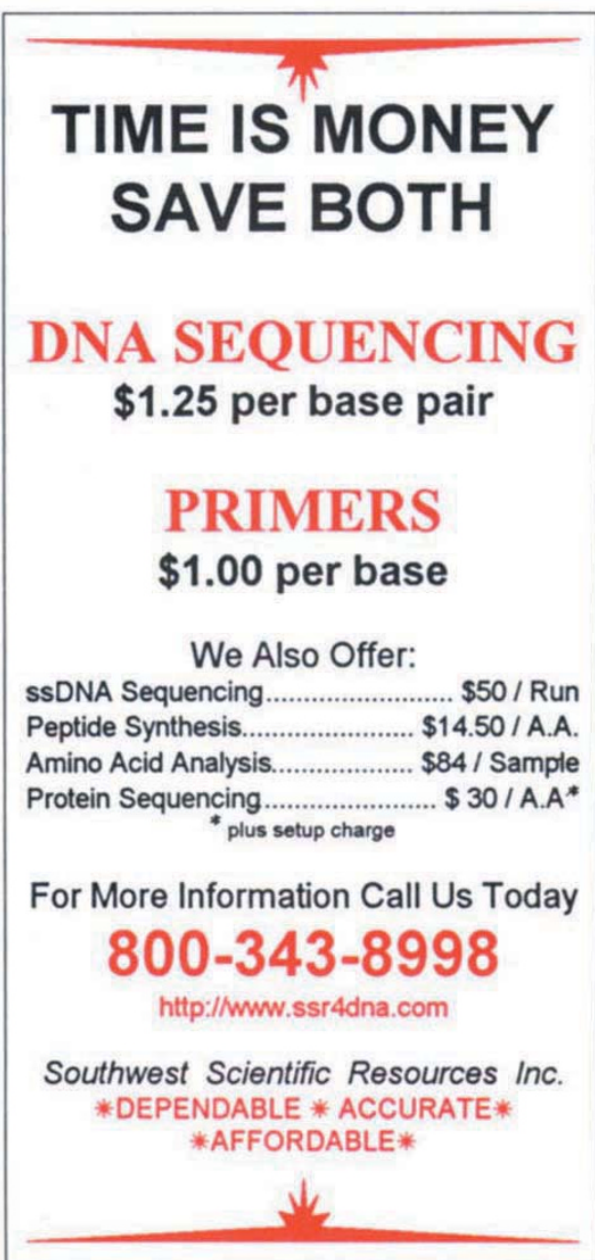

